Cilt / Volume 3, Sayı / Issue 2, 2020, pp. 85-96

E - ISSN: 2636-7718

URL: https://journals.gen.tr/index.php/arts

DOİ: https://doi.org/10.31566/arts.3.007

Araştırma Makalesi / Research Article

\title{
SAFAVID CERAMICS THROUGH THE EYES OF EUROPEAN TRAVELLERS
}

\author{
Vafa AFSHAR* \\ * Department of Ceramic, Faculty of Fine Arts, Hacettepe University, \\ TURKEYe-mail: afshar@hacettepe.edu.tr \\ ORCID: https://orcid.org/0000-0002-2070-8167
}

Received: 8 March 2020; Accepted:30 April 2020

\begin{abstract}
The ceramic industry of Safavid Iran (1501-1732) represents one of the high points of the production of pottery in the world, and especially in the Islamic World. The present study aims to investigate Safavid ceramics from the accounts of European travellers and study their accounts about various aspects of Safavid ceramics. In this regard, dozens of travelogues of the Europeans who travelled to Iran during the Safavid era were studied. Travellers' accounts on Safavid pottery that reflected in their travelogues, not only describes pottery as one of the distinguished Iranian industries, sometimes they also provide remarkable unique information about the pottery industry, the centers of manufacturing, trade, and export of pottery which are discussed in detail during the paper. This paper shows that travellers' accounts are significant to the study of Safavid ceramic arts history.
\end{abstract}

Key Words: Safavid Ceramics, European Travellers, Pottery Industry, Safavid Iran 


\section{INTRODUCTION}

At the beginning of the sixteenth century, the Safavid took power in Iran and they remained in power for two centuries. Safavid period was the golden age for arts in Iran. In these periods, various cities such as Tabriz, Qazvin, and Isfahan were selected as the capitals. The city of Isfahan, in terms of architectural aesthetics and architectural decorations, shows the growth of arts and creativity, attention to the arts and artists in those periods.

The interests of the sultans of this dynasty, especially Shah Abbas I, were in arts and artists. Iranian craftsmen and artists were been encouraged to engage into the production of a cornucopia of cloths, ceramics, silks, carpets, porcelain, metal works, and brocades. The importance of art during this period has brought artistic flourishing and the pottery industry was influenced by this artistic boom. Safavid pottery is considered as a turning point in the history of Iranian art from various aspects. Although, our findings and information from Safavid pottery are based on archaeological remains, the written and textual information about this art from the Safavid era and even the later era is very insignificant.

The Safavid period is the golden age of Europeans traveling to Iran. As Iran opened up to the world during the reign of the Safavid, the country became a favourite destination for Europeans. Diverse in motives and mandates, visitors ranged from diplomats, missionaries eager to save souls, merchants keen to make their fortune. Those who wrote down their impressions offer a multifaceted panorama of Iran, elevating our knowledge about the Safavid realm to an unprecedented level. Therefore, one possible source for studying the ceramic industry in Safavid Iran is the travelogues and notes that European travellers have left behind. The concern of the present study is to investigate ceramic industry in Safavid Iran with accounts provided by contemporary European travellers of the Safavid period. On the other hand, travellers account will give us more insight into the pottery industry of this age and provide us with more useful information on different aspects of pottery art. It is undoubtedly necessary to emphasise that it shouldn't be presumed that such works are without mistakes or even misleading analyses. Writers sometimes due to private or political reasons and many at times as a result of mistakes in misinterpretations have recorded incorrect information in their reports. With the approach in this paper, the travelogues related to the Safavid period and the status of the pottery of the era from the viewpoint of European travellers' studies.

\section{ACCOUNTS OF TRAVELLERS}

As we said, the Safavid pottery industry from different aspects is a turning point in the history of Iranian art. Considering that the main purpose of this research is to show the Safavid ceramics art in a precise look and impartial views of foreign travellers. In this regard, accounts of dozens of that age's travellers was studied. Most contemporary European travellers of the Safavid period devoted little attention to the ceramic industry of Iran. Some of them wrote a few pages on the subject, others wrote no more than a paragraph or two, and still, others made their remarks in one short sentence. Yet, when we combine the accounts of all the travellers, we can create a representative accurate report of both how much and how little these travellers actually knew about ceramics art in Iran. My objectives in the following paragraphs are to introduce the travellers and their accounts, to describe briefly specific details from the travellers' accounts about Iranian arts. And in order to clarify the issue and examine more precisely the approach of the travellers to the Safavid pottery and a better understanding the pottery industry of the period from the perspective of foreign travellers, the abstract and the main references of travellers are presented in a comparative way. 


\subsection{Don Garcia de Silva Figueroa}

Don Garcia de Silva Figueroa was a Spanish diplomat. "In 1612 Philip III, King of Spain chose de Silva Figueroa as his ambassador to the court of Shah Abbas I, the Safavid monarch" (Loureiro, 2016: 179). During his stay in Persia, Figueroa extensively travelled throughout Persia. He visited the cities of Shiraz, Qom, Isfahan and many others. He also went to see the ruins of Persepolis (Ishraqi, 2000: 62).

He wrote a full account of his travels. His memory contains a great deal of detailed information relating to Persian history, culture and society. He also wrote about the ceramic arts in Safavid Iran. When he visited Isfahan, The Royal Mosque of Isfahan (Picture 1) wasn't completed yet, but the rare colours and designs of the tiles that were being mounted in the building were so stunning that it made the Western traveller to write. He wrote:

"The building of this mosque is not over yet, but it can be guessed from what is already evident that it will be so beautiful and luxurious. Its entrance, which has a very tall dome, is completely decorated with plant motifs and with the best tiles. The mosque covers the entire end of the square, and workers are cutting and tiling pieces of different colours ceramics. These tiles have designed rare motifs that have never been seen like them across the East." (Figueroa, 1984: 213)

In his visit to Shiraz, Figueroa also described the mosque's tiles works in Shiraz. This beautiful mosque, built on the command of the ruler of Shiraz, has its interior part adorned with magnificent and elegant designs and has a magnificent view of the outside. The beautiful and delicate tiles of this mosque compete with the finest and most beautiful examples in Asia (Figueroa, 1984: 161).

Picture 1. Main entrance to Royal Mosque, Safavid Period, Isfahan, Iran

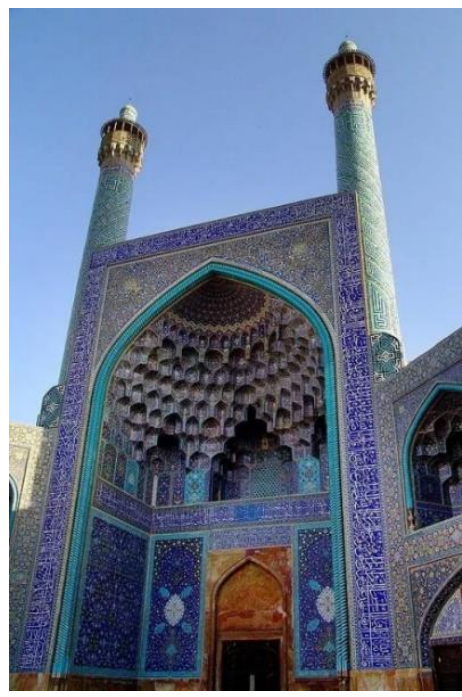

Reference: https://en.wikipedia.org/wiki/Shah_Mosque_(Isfahan)

\subsection{Adam Olearius}

"In 1637 Frederick II, Duke of Holstein sent a delegation of one hundred men to the court of Shah Safi in Isfahan. The official mission of the envoy, led by Philip Crusius and Otto Bergman, was to secure silk trade relations with Iran across Russia." (Bel, 1978: 11) Adam Olearius accompanied the embassy in the capacity of secretary, and during his stay in Iran, he produced an account of the embassy's travels. Olearius has been in Iran for one and a half years and has spent a large part of this period traveling to different regions of Iran and has studied the 
cities of Iran, especially Esfahan, Shah Safi court and the community, traditions and customs of Iran (Olearius, 2006: 6).

In his travelogue, Olearius wrote: "The ceramic industry in Iran has developed well during the Shah Safi era and he explains that during the Shah Abbas I period in Ardabil, two Chinese businessman had ceramic shops, and many Iranian potters were imitating their work. They tried, but they did not succeed until Shah Abbas I brought Chinese artists to Iran. Under their supervision, Iranian blue and white dishes, which were very similar to the original (Picture 2) competed with the dishes of the principle of making China with almost the same acceptance." (Savory, 2007: 142).

Picture 1. Plate with underglaze painting inspired by Chinese blue and white porcelain, Safavid period, Metropolitan Museum

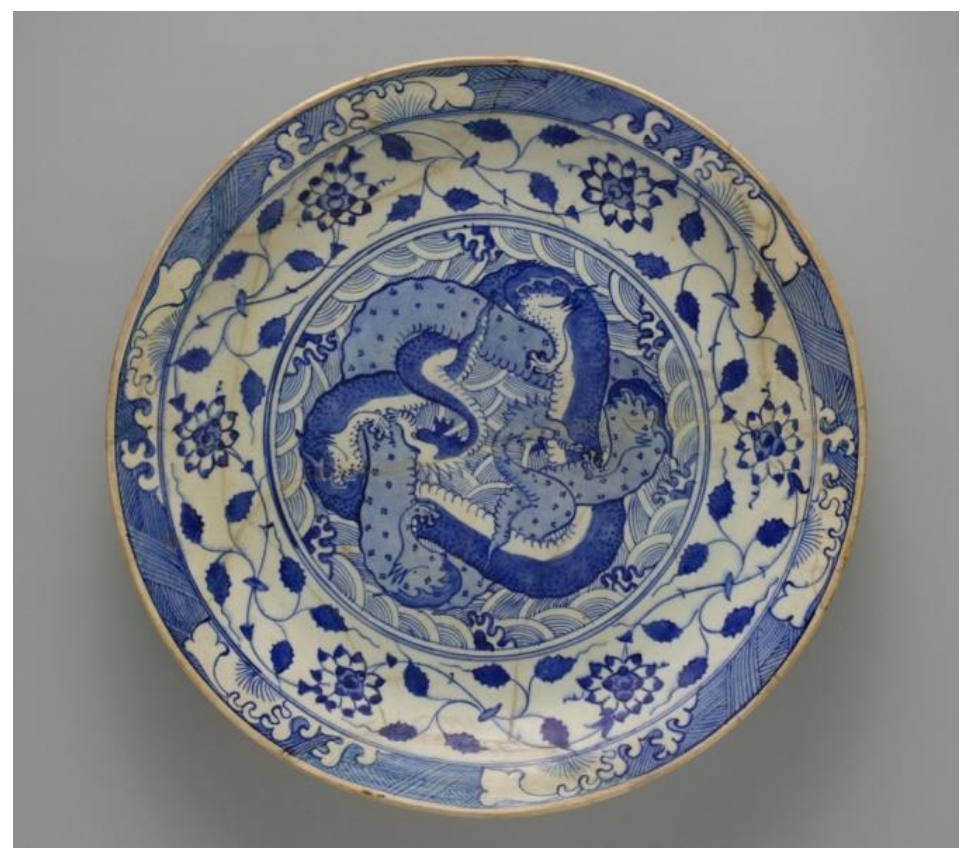

Reference: https://www.metmuseum.org/art/collection/search/451804

In his visit to Qom, Olearius considers the city as one of the Iranian pottery centers and writes that the most important handicrafts here are sword-plating and pottery. Different pottery dishes are produced in this city and these ceramic dishes are exported to all cities of the country (Olearius, 2006:163).

\subsection{Jean Baptiste Tavernier}

"Jean Baptiste Tavernier, a French Protestant jewel merchant and inveterate traveler made six journeys to Persia between 1632 and 1668. He was on the move again to Iran when he died in Moscow at the age of eighty-four" (Williamson, 2013: 66). The purpose of his six journeys to Asia, mainly to Iran and India, was to buy uncut gems in Asia, cut and set them in Europe, and return to Asia and sell the finished products at handsome profits (Tavernier, 2004: $9-7)$.

Tavernier wrote on several travelogues in the description of his travels. All these travelogues are full of valuable information that cannot be found in other books similar to them. Tavernier's account is a valuable treatment of Safavid Iran. He described, in minute detail, the various routes he travelled and provides interesting descriptions of Iranian culture and life. For our purposes, ceramic industry in Safavid Iran. Tavernier provided a valuable information about Safavid pottery industry. Tavernier described pottery as one of the most distinguished Iranian 
industries and believed that the ceramics made with Kerman's clay were superior to the Nevers ceramics produced in France, because Iranian ceramics appears to be whitish outside when broken and they do not heat up when hot liquids are poured into them as the Nevers ceramics do. And this is considered an important privilege for Iranian ceramics (Tavernier, 2004: 270).

In his travelogue, Tavernier also referred to ceramic manufacturing centers and wrote: "Iranian dishes are made of red copper, which is often whitened with a layer of tin because they do not use silverware that is forbidden in Islam. The king's dishes are made of gold with great quality. Iranians have some beautiful ceramic dishes for their own use, which are being built in their country, especially in Kerman (picture 3) and Shamakhi" (Tavernier, 2004: 309).

Picture 2. Plate with underglaze painting, Safavid period, Kerman, Aga Khan Museum

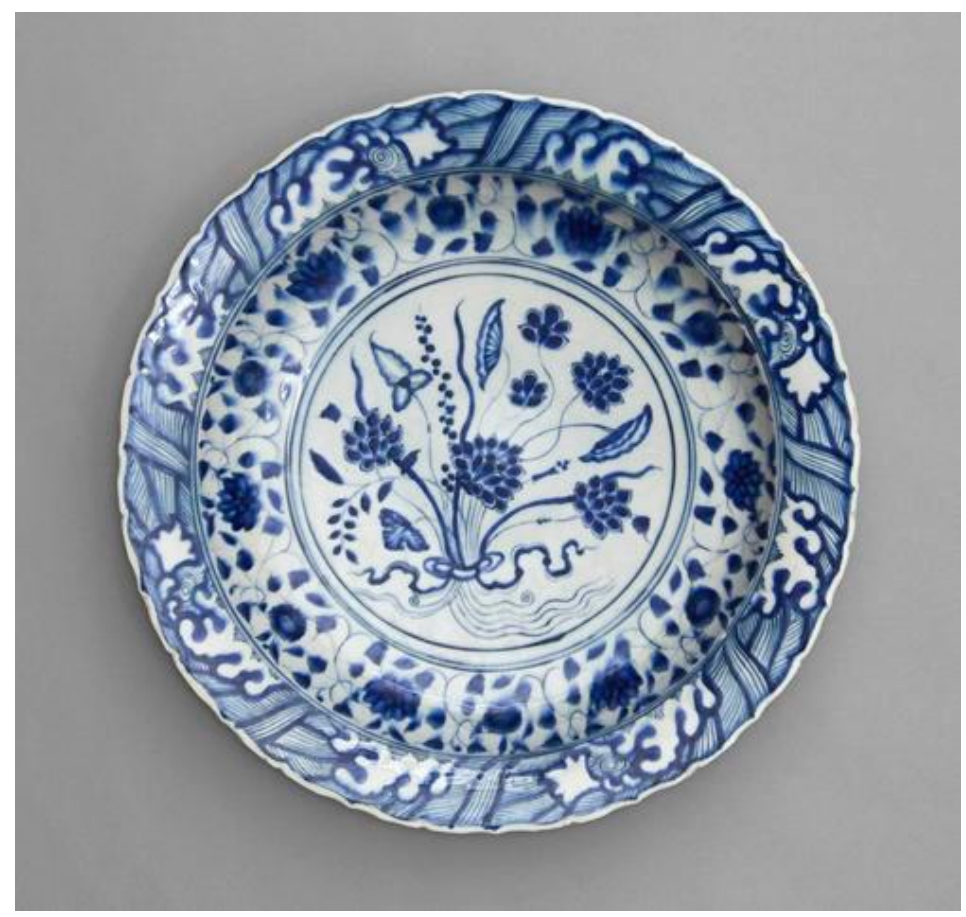

Reference: https://www.agakhanmuseum.org/collection/artifact/dish-akm588

\subsection{Raphael du Mans}

Father Raphael du Mans, a French Capuchin, spent fifty-one years in Iran beginning in 1647. In 1645 he was sent on his first foreign mission. He stayed first at the Capuchin monastery in Cairo, then, in May 1647, he joined the French Capuchins at Isfahan. On the basis of Minorsky's evaluation of du Mans, "The author was one of the best Persian scholars of the time," wrote Minorsky, "and was employed by the Shah as an interpreter in the more important negotiations. His book is remarkable as a first-hand account of the situation, covering as it does a whole range of Persian topics and using an exact terminology." (Minorsky,1943:7)

Raphael du Mans, whose decades-spanning residence in Isfahan made him exceptionally knowledgeable Safavid society and culture, wrote about pottery in the Safavid period: The work of Iranian pottery artists is better than the Nevers and Orléans pottery artists in French because the interior and exterior of the pottery vessels made in Iran are made whitish. They are decorated with Venetian azure. Ceramics which made in Kerman can hardly be distinguished from original Chinese ceramics. Only the ceramics made in Kerman crack, when a hot liquid is poured into it, while original Chinese ceramics are resistant to it (Du Mans, 1890: 196). 


\subsection{Jean Chardin}

"The Frenchman who spent the most time, and gained the most insight, into Persian life and customs was Jean Chardin. Chardin spent the equivalent of ten years in Persia between 1665 and 1677, Chardin was a Protestant and a jewel merchant who travelled independently to Persia for commercial purposes" (Williamson, 2013: 68). During his first visit, he began his study of Persian and Turkish language and rapidly attained fluency in both. Throughout his residence in Iran, Chardin studied Iran's politics, literature, history, arts, customs and resources with minute thoroughness (Penzer,1972).

Chardin has described in detail about the Persian Empires in the Safavid period, describing the pottery of this period as follows:

Th earthenware, or chinaware, as they call it, is likewise one of the most curious manufactures; they make it all over Persia but the finest earthenware produced in Shiraz, the metropolis of Persia; at Mashhad, the capital of Bactriana; at Yazd and Kerman, and especially in a village of Kerman, called "Zarand". The Earth, whereof that ware is made, is pure enamel, both within and without, like the chinaware: The grain of it is as fine and transparent as that is; whereby it happens that one is often deceived in that earthenware and that one cannot distinguish it from chinaware: you meet sometimes with some Persian Ware that exceeds the chinaware so beautiful and lively is the varnish of it: I speak still of the new chinaware, and not of the old. The pieces which the Persian potters called Cacoiper, or earthenware bakers, make best, are the enamel tiles painted and cut out in imitation of Moresk work. Indeed, nothing can be seen livelier and brighter in that kind or drawn finer and more regular. The Persian earthenware is fire-proof; so that, they not only boil water in it without breaking, but they even make cooking pots of them. It is hard enough also to make mortar for grinding colours and other materials. The materials of that fine enamel is glass, and little river pebbles pounded very small, together with a little mold mixed with them (Penzer,1972: 267-268).

Chardin has stayed in Qom for a few days in order to reach the city of Isfahan. He wrote in the description of the markets of Qom: Although this city is not commercially valid, it has good markets in which everything is available. The large amounts of soap, white and glazed pottery, the sword blade is the most important exporter of this city (Chardin, 1993: 521).

In his travelogue, Chardin wrote about the gifts of the Dutch company's representative to Shah Abbas II:

"In the year, 1666, an ambassador of the Dutch company, called, Hubert de La Haye, having brought the king a present of a great many valuable things, and amongst the rest, fifty six pieces of old chinaware, The king, as soon as he saw it, began to smile, and asked scornfully: what are these things? I heard that the Dutch mix Persian ware with the chinaware and import it into Holland. In his accounts, Chardin, wrote in support of the words of The king: This certainly shows that the Dutch have improved themselves much in Persian, in the way of making earthenware, and they would make it still better if they had the same clear water, and the same clear air they have in Persia. The skillful workmen in earthenware, ascribe to the water the gloss of the colour, as has been already observed, and say that there are some waters that dissolve the colours and make them spread, whereas there are others that contract and fix them" (Penzer, 1972: 267-268).

During the reign of Shah Abbas II, the pottery industry was so thriving that potters competed in the pottery industry to showcase their artistic perfection. Chardin wrote in his account that: 
"There is a story that the potters of the town of Yazd in Kerman, sent once, by way of challenge, to the potters of Isfahan, an earthen dish that held twelve pound weight of water, and weighed itself but a Dram; and potters of Isfahan sent them back a dish of the same bigness and form, which held but a Drachm of water, and weighed twelve pound weight. There are some tradesmen in Persia whose employment is to mend Earthen Ware and glass. They join the pieces together, and sew them with very small tin wire, and rub the seam over with a kind of chalk or small lime: A dish so mended, holds waters as well as before." (Penzer, 1972: 268)

Ceramics produced in Persia during the Safavid period were very beautiful and high quality. According to the descriptions of Chardin, these ceramics were not used only in the life of ordinary people but these Persian Wares were used alongside gold and silver containers in court banquets. For example, Chardin wrote in the description of the luncheon of the ruler of Shiraz:

"All the dishes used in great banquet are silverware or ceramic ware. Some of these ceramics are more valuable than silverware, and some of them are green. Eating in these ceramic wares is really great and fresh and they are very brilliant that seem to be they were produced on the same day, but there is no such glow and refreshing in European ceramic wares." (Chardin, 1993: 1358)

Chardin was very interested in the architecture of Isfahan. One of the buildings that he wrote about is Isfahan Royal Mosque. In his explanation of this mosque, Chardin described it and its tiles. According to the records, Chardin's writings on tiles are as follows:

The group of craftsmen who are called Kashi-Paz make the tiles from special clay and mold them very beautifully with attractive designs. These designs are unique in their kind. For example, the decoration of the Royal Mosque is truly magnificent and it's alike cannot be found in European buildings. These decorations include thousands of Mogharnas, which are golden and azure. The walls are covered with beautiful enamel tiles. These tiles are decorated with flat flowers motifs and margins on which verses of Quran have been involved. After this explanation, it must be said that the Persians are truly miraculous in the art of flowers and plants design, and both on plaster and on enamel tiles and ceramics wares and they are much ahead of Europeans (Chardin, 1993:1434-1431).

\subsection{Engelbert Kaempfer}

"Kaempfer, a German physician, and traveller was born in 1651. He was appointed as secretary of a Swedish embassy to the Persian courts in 1683" (Bowers,1966: 238-239). The purpose of the Swedish legation was to gain direct access to the much coveted Oriental goods and raw materials, thereby avoiding the added costs of the Dutch carrying trade off the long sea routes of South Africa. He was one of the keenest observers of foreign cultures of his time. Although his observations while in Persia did much to enhance Western knowledge of the Safavid period. When Kaempfer arrived in Isfahan he followed his inquiries while employed at the Swedish Legation. During his stay in Isfahan he carried out a methodological survey of the town. He walked several times through it, visited various places, and completed a comprehensive investigation of its structure (Ishraqi, 2000: 220-221).

The tomb of Haroon Velayat originated from the early Safavid period is one of the places that Kaempfer has been exploring and describing it. He wrote in his descriptions about its tiles: this mosque is covered with clean and charming blue tiles. As the viewer thinks, it is made of a piece of stone. Their tiles are called "patchwork stone". Because they imagine that the grave of the Great Haroon is in this mosque, this mosque occupies the name of Haroon (Kaempfer, 1981: 192). 
Another place that Kaempfer described its tiles in his travelogue was the Sheikh Lotfollah Mosque (picture 4). Kaempfer wrote: "On the eastern side of the Great Square, the Sheikh Lotfollah Mosque attracts everyone's attention with it's super magnificent tiles. These tiles, all decorated in different ways, are so beautiful that it is difficult to describe them." (Kaempfer, 1981: 193)

Picture 3. Sheikh Lotfollah Mosque, Safavid period, Isfahan, Iran

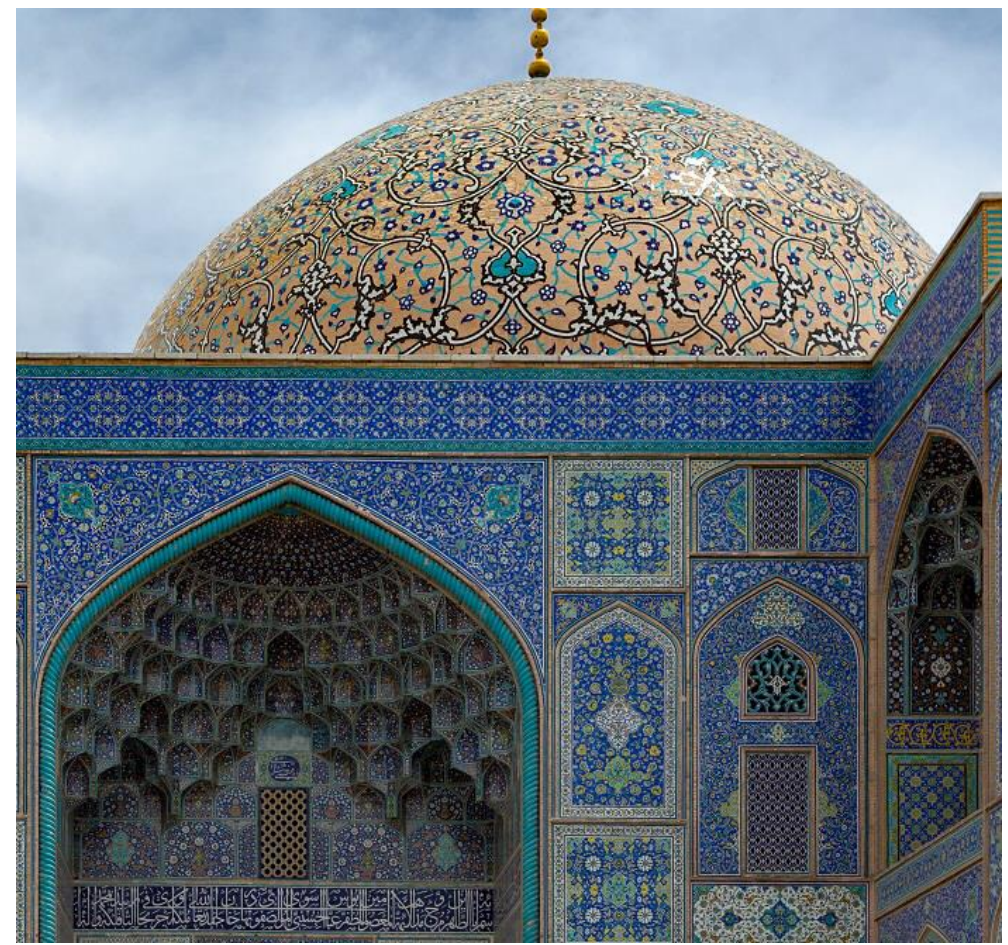

Reference: https://commons.wikimedia.org/wiki/File:Sheikh_Lotfollah_Mosque_(39440128050).jpg

\subsection{Nicolas Sanson}

"Sanson was the French missionary who went to Iran as an Apostolic missionary in 1683 and stayed in the country for almost a decade. He spent three years in Isfahan" (Bel, 1978: 15). In his travelogue, he fully described the manners, customs, government, religion and arts of Safavid Persian.

Sanson wrote about the beautiful tiles of The Sheikh Lotfallah Mosque and Royal Mosque in Isfahan: On the East side of this place, and over-against the King's Palace, appears a stately Mosque, a fine mosque. Whose dome is a very bold work, by reason of its largeness. The outside of it is painted like porcelain, and its tiles encompassed round with a white list of two foot broad, within it are carved number of great Persian characters. In one of the corners of this place, on the west-side, was another great mosque, The Great Royal Mosque. The gate of this mosque is a piece of art that might very well amaze the most skilful architects of Europe. These tiles have extraordinary height, and composed of marble of many colours, and have also a white list above it at the top, which continues all over the porticoes and body of the mosque. The front is painted with varnished azure and sometimes intermixed with many leaves and festoons of gold (Sanson, 1967: 35-36).

During his stay in Isfahan, Sanson also visited The Royal Art Studios and wrote about them. The king has a large number of foreign workmen in The Royal Studios and the King personally chooses workmen. The French watchmakers and highly skilled Chinese potters worked at the studios of the King of Iran, but he respects the French most, of whom he has at present many skilful and excellent watchmakers and jewellers. He gives them very magnificent 
salaries and there are some of them that receive 2500 Livres per month, and together with it all necessary provisions, amounts to a great sum (Sanson, 1967: 52).

\subsection{Gemelli Carreri}

"In 1693, the Italian lawyer Giovanni Francesco Gemelli Careri set out on a five-year journey around the world. Gemelli Carreri was in Iran in the 1690s" (Colburn, 2017: 181). Carreri came to Iran during the reign of Shah Suleiman and participated in the coronation of Sultan Hoessein. During his stay in Iran, he visited the cities of Jolfa, Tabriz, Qom, Isfahan, and Shiraz wrote in his notes a valuable commentary on these cities. In his accounts, he gives a short description of the ceramics and tiles in Safavid Iran. In a report from a visit to Tabriz, Carreri makes a very interesting description of the mosque's tiles in Tabriz, and Iranian tiles seem to have been very interesting and admirable for all European travellers. In his travelogue, Carrie wrote:

"In Tabriz, I went to the mosque next to the garden. This mosque was one of the most beautiful mosques in Tabriz. At the entrance of this mosque was a magnificent example of Iranian architecture and mosaics and tiles art. These tiles were made in blue, violet, white and black colours. Inside the mosque, like the entrance, was covered with colourful and exquisite tiles, and several geometric lines gave them a special effect. The dome of the mosque, which was thirty-four feet in diameter, has been decorated with colourful gold and lazuli tiles and mosaics and exquisite paintings. Out of the dome, green tiles were covered with white and black flowers, which made them outstanding and stunning" (Gemelli Careri, 1969: 28-30). travelogue:

Carrey has provided valuable information about Iranian handicrafts and arts in his

In Isfahan, the gold and silver industry and silk production are prevalent. The ceramic industry also has been further developed in Iran, especially in Kerman, making fine ceramic dishes. These ceramic dishes are often white colour. And these enamels are very durable, strong and valuable (Gemelli Careri, 1969: 148).

\subsection{La Belle Brelandiere}

Louis XIV, King of France was determined to establish a solid relationship with Iran, based on the official trade agreement, and in order to reach this agreement and provide the necessary preparations, a journey was arranged. Marie Petit, known in history as La Belle Brelandiere, has been appointed Louis XIV's first official envoy to the Safavid Shah Sultan Hosein. During this trip, Marie Petit wrote a full account of her travels. Petit's accounts contain detailed information relating to Persian history, culture and society.

In her visit to Tabriz, Marie Petit referred to the ceramic factory in Tabriz and wrote: In Tabriz was a factory that produced ceramics in different colours (picture 5) but the dominant colour in all of them was blue. Meanwhile, flower designs such as rose and tulips have greatly added the beauty of these products. The Iranian people see the products of this factory as mere artworks, and Tabriz ceramic wares have a special place for foreign customers (Grès,1991: 178). 
Picture 4. Earthenware with underglaze painting, Northwestern Iran, Safavid Period, Cincinnati Art Museum

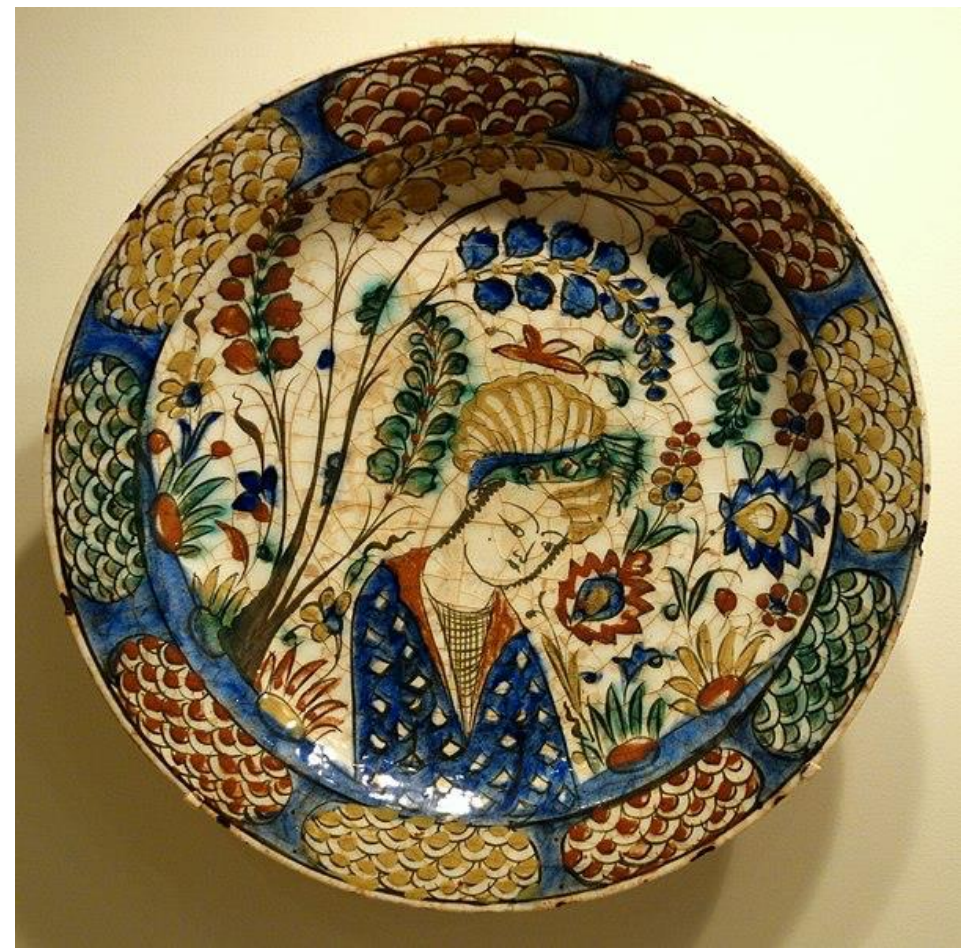

Reference: https://en.wikipedia.org/wiki/Kubachi_ware\#/media

As noted above, according to the accounts of Marie Petit at the end of the Safavid period in Iran, beautiful ceramic wares were not only used in practical purpose and the Iranians considered these dishes as artworks. In affirmation to this, Marie Petit in her travelogue wrote about the beautiful and stunning decorations of chancellor's house:

The decor of that house was really beautiful and stunning. The ceilings of all the halls were made of gold. The walls were covered with beautiful tiles or colourful and precious rugs. She wrote that:

\begin{abstract}
"I watched carefully the art objects in that house. These objects were arranged on very large silver tables in the large halls, among them were bronze sculptures, ceramic dishes, and Enamel jewellery. All the rooms were full of silk, velvet and leather cushions and pillows. On the tables there were fine glasses, golden jars, vessels, and ceramics brought from China, and other many beautiful artistic objects. The chancellor was fond of art and was interested in collecting artistic pieces to his house. For example, he had beautiful ceramic plates baring painted image of a sphinx with a human face. Most of these ceramic works were previously produced in Kashan, and their production dates back to the fourth and eighth centuries. Of course, Kashan was a city that was always central to attracting artists. In the year 1200, Seyyed Shams al-Din al-Hasani with the beautiful tiles he created, became well-known in this field in Kashan" (Grès, 1991:198-215).
\end{abstract}

\title{
3. CONCLUSION
}

The study of these travelogues, that most of them belong to French during the Safavid era, shows that during the Safavid period, the pottery industry in Iran was very advanced. During this period, the potters began to make excellent works and as it appears in travelogues of travellers who have travelled to Iran on that date. The production of pottery in all parts of Iran has been common. Like Mashhad in the east, Tabriz and Shemikhi in the northwest and 
many of the central cities of Iran such as Kerman, Zarand, Qom, Shiraz, Isfahan, Kashan, and Yazd.

The most important fact about the history of pottery during the Safavid period was the extensive exchange of techniques and designs that took place between Iran and China. And in some way blended with the taste of Iranian potters and caused the production of durable pottery. Noted in the accounts of most foreign traveler Ceramic Tiles and other pottery works have attracted the attention of most foreign travellers. In their travelogues, they have expressed their amazement at the rare designs of the tails. And they also emphasize the superior quality of Iranian pottery and tiles on European samples. Ceramic tiles and calligraphic application in the decoration of tiles of Royal mosque and Sheikh Lotfollah mosque in Isfahan and numerous geometric designs in the interior tiles of Tabriz Mosque have attracted our traveler's attention. In general, Iran's pottery relations with China's pottery have become more competitive and its main objective has been to win the world market. As we mentioned earlier, according to Chardin's account, in European markets, Iranian ceramic products were sold in the name of the Chinese product.

In terms of the quality of the Iranian ceramics works, most travellers point to the superiority of Iranian ceramics on Chinese ceramics and European samples. And also, in their accounts, travellers emphasis on the brightness of the tiles, the gloss of the azure used in them, the elegance of Iranian ceramics and their resistance to heat, and finally the whiteness of both inside and outside of them.

Iranians have their native and foreign styles in their regions in the 15th and 16th centuries, taking advantage of their pre-existing cultural heritage for producing their ceramics.

In the field of pottery materials, while referring to the technical principles of making tiles and ceramic dishes, the quality of soil around Kerman has been emphasized. They also have been mentioned to the production of Venetian azure from blue glass bottles imported from Italy.

In the field of trade and export of Safavid pottery, there is a definitive record of European travellers. Based on this information, we find out that not only ceramics produced in some Iranian cities such as Qom were exported to other Iranian cities, but also products from Kerman and Mashhad based on Chardin's account were exported to Europe. According to the account of Marie Petit, Tabriz ceramic wares have a special place for foreign customers. Also, the same account indicates that Chinese ceramics were not imported only by Iranian merchants or through foreign traveler gifts, and according to Olearius observations in Ardabil, the Chinese themselves also traded Chinese ceramics in Iran.

By exploring travelogues, European travellers have seen the art of pottery and tiles artfully adapted. In most cases, they compare the works of Iranian pottery with Chinese and even European samples. And the result of this comparison, as reflected in their accounts, indicates the advancement of the pottery industry and the production of superior ceramics in the Safavid era. Not only in the travellers' point of view, Persian ceramic wares are not different from the chinaware also the works of Iranian pottery artists are superior to the works of European pottery artists. As Du Mans and Tavernier mentioned in their accounts to the superiority of Kerman's pottery on the pottery of Nevers and Orléans in French. It should be noted that travellers who have had a business trip to Iran, such as Olearious, Tavernier, Chardin, La Bella Brelandiere, wrote the most and accurate information from the centres of pottery production, techniques, quality of pottery art and compared it with Chinese and French samples and even to extent of Persian wares export in Safavid Iran. But other travellers generally described the pottery art, especially tiles and its use in the architecture of the Safavid era. 


\section{REFERENCES}

BEL, R. J., 1978, Traveler's accounts as a source for the study of religion in Safavid Iran, Master Thesis, Department of Oriental Studies, The University of Arizona.

BOWERS, J. Z., 1966, Engelbert Kaempfer: Physician, explorer, scholar, and author, Journal of the history of medicine and allied sciences, 237-259.

CHARDIN, J., 1993, Sir John Chardin's Travels in Persia [سفرنامه شو اليه شاردن], Entesharate Tus, Tehran.

COLBURN, H. P., 2017, Gemelli Careri's Description of Persepolis, Getty Research Journal, 9(1), 181-190.

DU MANS, R., 1890, Estât de la Perse en 1660, par le P. Raphael Du Mans, Supérieur de la Mission des Capucins d Isfahan, ed, Ch. Schefer, Paris.

FIGUEROA, G.d.S., 1984, L'ambassade de D. Garcias de Silva Figueroa en Perse [ سفرنامه دن [خارسيا دسيلو ا فيكوئروا

GEMELLI CARERI, G.F., 1969, Voyage du tour du monde [سفرنامه كاررى], Edareye Kole Farhang ve Honare Eslami, Tabriz.

GRÈS, Y., 1991, La belle Brelandière ambassadeur en Perse [سفير زيبا], Entesharate Tehran, Tehran.

ISHRAQI, F., 2000, Isfahan, in foreign travelers' viewpoint, Atriat, Tehran.

KAEMPFER, E., 1981, Am Hofe des persischen Grosskönigs [ سفرنامه كميفر], Kharazmi, Tehran.

LOUREIRO, R. M., 2016, The History of Tamerlan in Don García de Silva y Figueroa's Comentarios The Spanish Monarchy and Safavid Persia in the Early Modern Period: Politics, War and Religion, 177-198.

MINORSKY, V., 1943, Tadhkirat Al-Muluk: A Manual of Safavid Administration, Luzac and Co, London.

OLEARIUS, A., 2006, Vermehrte newe beschreibung der muscowitischen und persischen reyse so durch gelegenheit einer Holsteinischen gesandschafft an den russischen zaar und könig in Persien geschehen [سفرنامه آدام اولئاريوس], Ebtekare Nou, Tehran.

PENZER, N.M., 1972, Sir John Chardin's Travels in Persia, AMS Press, New York.

SANSON, F., 1967, Voyage ou rélation de l'état present du royaume de Perse [سفرنامه سانسون], Ebnesina, Tehran.

SAVORY, R., 2007, Iran under the Safavids, Cambridge University Press.

TAVERNIER, J.B., 2004, Tavernier's Travelogue [سفرنامه تاورنيه], Niloofar Publisher, Tehran.

WILliamSON, C., 2013, Safavid Persia Through the Eyes of French Travellers, The La Trobe. 